\title{
Short-chain fatty acid formation at fermentation of indigestible carbohydrates
}

\author{
By Åsa Henningsson, Inger Björck and Margareta Nyman
}

\begin{abstract}
Short chain fatty acids (SCFAs; acetic, propionic and butyric acid) are formed during bacterial fermentation of carbohydrates in the colon. The interest in SCFA production is related to an increasing body of knowledge of the physiological effects of these acids. SCFAs are important anions in the colonic lumen and serve locally as nutrients for the mucosa cells, stimulating mucosal proliferation and blood flow. Especially butyric acid has been emphazised. It is the main energy substrate for the colonocytes and has been suggested to play a role in the prevention and treatment of diseases of the colonic mucosa, such as distal ulcerative colitis and cancer. SCFA production decreases the luminal $\mathrm{pH}$, and may thereby stimulate mineral absorption and reduce secondary bile acid formation in the colon. Colonic generation of SCFAs has also been related to systematic and metabolic effects, e.g. SCFAs may influence the motility along the gastrointestinal tract and propionic acid has been suggested to inhibit the cholesterol synthesis from acetic acid in the liver. The SCFA formed at fermentation is quantitatively and qualitatively influenced by the type and amount of carbohydrate substrate. Further, certain combinations of carbohydrates may have synergistic effects on the SCFA pattern and may also shift the site of fermentation. This opens possibilities to design foods with tailored features regarding SCFA release in the human colon with potential health implications. There is a potential that in the future it will be possible to control SCFA production in the colon regarding pattern and place for release. Keywords: Carbohydrates, dietary fibre, fermentation, SCFA, resistant starch
\end{abstract}

\section{Introduction}

In Western societies, about 20-60 g of the daily carbohydrate intake escapes digestion and absorption in the small intestine and reaches the colon as a potential source for fermentation (1). A considerable microbial flora, which amounts to $10^{11}$ bacteria per gram content, is present in this organ. The colonic microflora contains about 400 to 500 bacterial species, but most are in small numbers (2). Most of the microorganisms are saccharolytic. The fermentation products, with carbohydrates as fermentation substrate, are mainly short-chain fatty acids (SCFAs; acetic, propionic and butyric acid) and gases $\left(\mathrm{CO}_{2}, \mathrm{CH}_{4}\right.$ and $\left.\mathrm{H}_{2}\right)$. These end products are either excreted in the stool or absorbed from the colon (Figure 1). In the 1960s, SCFAs were believed to be poorly absorbed, causing diarrhoea through osmotic fluid retention in the stool. However, it is now known that about $90 \%$ of these SCFAs are rapidly absorbed by the colon, stimulating water and sodium absorption (3). Fermentation of indigestible carbohydrate to SCFAs thus reduces the osmotic load and there is also increasing evidence that the individual SCFA may have specific roles, including beneficial health implications.
\end{abstract}

\section{Nutritional implications of short-chain fatty acids}

The SCFAs absorbed from the colon can be utilized as an energy source by the host, but they contribute only to a small part (5$10 \%$ ) of total energy in healthy individuals on Western diets (4). The colonic mucosa obtains its energy by oxidizing mainly SCFAs in the order of butyric>propionic >acetic acid (5). The SCFAs that escape metabolism in the colonocytes enter the

\footnotetext{
Åsa Henningsson*, MSc, Inger Björck, Prof., Margareta Nyman, Prof. Applied Nutrition and Food Chemistry, Center for Chemistry and Chemical Engineering, Lund University, P.O. Box 124, SE-221 00 Lund, Sweden *Correspondence: E-mail: Margareta.Nyman@inl.1th.se

The article is based on a lecture presented at the meeting Lactose intolerance revisited, Febuary 1-2, 2001, Stockholm, Sweden.
}

hepatic portal blood. Acetic acid is utilized by the liver where it is transferred into Acetyl-CoA, which can act as a precursor for lipogenesis (6), but also stimulates gluconeogenesis (7). Low concentrations of acetic acid can also be detected in venous blood in peripheral tissues (8).

SCFAs formed at fermentation of carbohydrates in the colon have been reported to affect carbohydrate metabolism (9). Thus, barley containing high amounts of fermentable carbohydrates improved glucose tolerance in healthy subjects compared to rice with a lower amount of indigestible carbohydrates. The effect may be ascribcd to propionic acid. Propionic acid is mainly metabolized in the liver and has been shown to inhibit gluconeogenis and increase glycolysis in rat hepatocytes (10). It has also been proposed that propionic acid may lower plasma cholesterol concentrations by inhibiting hepatic cholesterogenesis (11).

However, the results from studies examining the effects of propionic acid on cholesterol metabolism are not consistent.

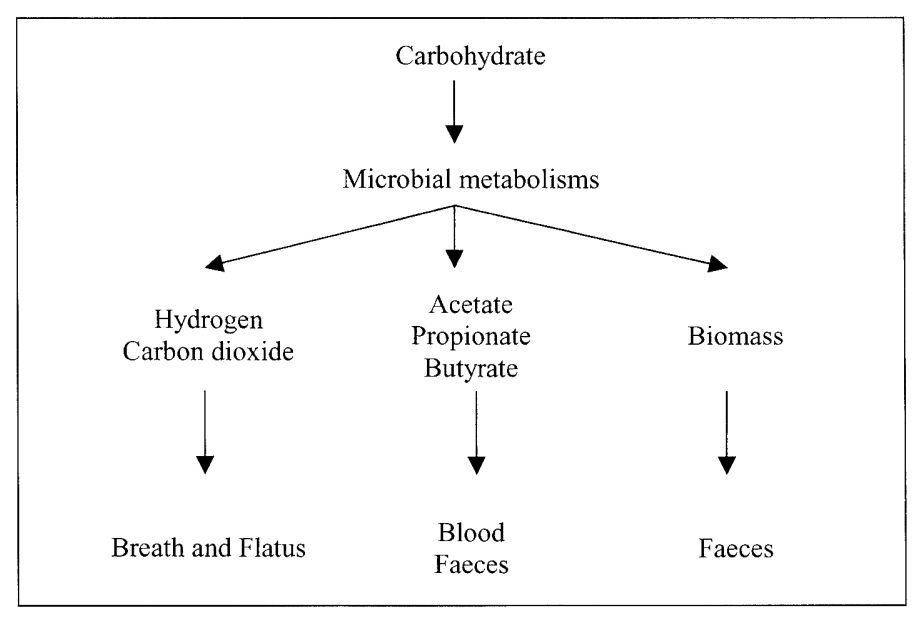

Figure 1. Carbohydrate fermentation in the human colon. 
Table 1. The pattern of SCFA formed from the fermentation of various carbohydrates by human faecal bacteria in vitro or in rat caecum.

\begin{tabular}{|c|c|c|c|c|c|c|}
\hline \multirow[t]{2}{*}{ Carbohydrate } & \multirow[t]{2}{*}{ Composition } & \multicolumn{3}{|c|}{ Molar distribution of SCFA (\%) } & \multirow[t]{2}{*}{ Model } & \multirow[t]{2}{*}{ Ref } \\
\hline & & Acetic & Propionic & Butyric & & \\
\hline Cellulose & Glucose & $\begin{array}{l}61 \\
61\end{array}$ & $\begin{array}{l}25 \\
20\end{array}$ & $\begin{array}{l}14 \\
19\end{array}$ & $\begin{array}{l}\text { Rats } \\
\text { In vitro } 48 \mathrm{~h}\end{array}$ & $\begin{array}{l}63 \\
64\end{array}$ \\
\hline $\begin{array}{c}\beta \text {-Glucan (barley) } \\
\text { (oat) }\end{array}$ & Glucose & $\begin{array}{l}69 \\
43\end{array}$ & $\begin{array}{l}15 \\
31\end{array}$ & $\begin{array}{l}15 \\
26\end{array}$ & $\begin{array}{l}\text { Rats } \\
\text { In vitro } 24 \mathrm{~h}\end{array}$ & $\begin{array}{l}48 \\
49\end{array}$ \\
\hline Guar gum & Mannose and galactose & $\begin{array}{l}62 \\
57\end{array}$ & $\begin{array}{l}27 \\
29\end{array}$ & $\begin{array}{l}11 \\
13\end{array}$ & $\begin{array}{l}\text { Rats } \\
\text { In vitro } 24 \mathrm{~h}\end{array}$ & $\begin{array}{l}48 \\
51\end{array}$ \\
\hline Inulin & Fructose & $\begin{array}{l}57 \\
51\end{array}$ & $\begin{array}{l}16 \\
14\end{array}$ & $\begin{array}{l}27 \\
35\end{array}$ & $\begin{array}{l}\text { Rats } \\
\text { In vitro } 24 \mathrm{~h}\end{array}$ & $\begin{array}{l}65 \\
66\end{array}$ \\
\hline Lactose & Galactose and glucose & 91 & 7 & 2 & In vitro $24 \mathrm{~h}$ & 59 \\
\hline Pectin & $\begin{array}{l}\text { Galacturonic acid, rhamnose, } \\
\text { galactose, arabinose }\end{array}$ & $\begin{array}{l}80 \\
80\end{array}$ & $\begin{array}{l}13 \\
11\end{array}$ & $\begin{array}{l}7 \\
9\end{array}$ & $\begin{array}{l}\text { Rats } \\
\text { In vitro } 24 \mathrm{~h}\end{array}$ & $\begin{array}{l}48 \\
49\end{array}$ \\
\hline Raffinose & Fructose and glucose & $\begin{array}{l}69 \\
63\end{array}$ & $\begin{array}{l}15 \\
12\end{array}$ & $\begin{array}{l}15 \\
25\end{array}$ & $\begin{array}{l}\text { Rats } \\
\text { In vitro } 24 \mathrm{~h}\end{array}$ & $\begin{array}{l}48 \\
52\end{array}$ \\
\hline Starch & Glucose & $\begin{array}{l}53-73 \\
38-66\end{array}$ & $\begin{array}{l}13-25 \\
12-26\end{array}$ & $\begin{array}{c}8-28 \\
22-36\end{array}$ & $\begin{array}{l}\text { Rats } \\
\text { In vitro } 24-28 \mathrm{~h}\end{array}$ & $\begin{array}{c}54-56 \\
49,50,52\end{array}$ \\
\hline Sugar beet & & $\begin{array}{l}67 \\
70\end{array}$ & $\begin{array}{l}21 \\
17\end{array}$ & $\begin{array}{l}12 \\
13\end{array}$ & $\begin{array}{l}\text { Rats } \\
\text { In vitro } 24 \mathrm{~h}\end{array}$ & $\begin{array}{l}67 \\
47\end{array}$ \\
\hline Wheat bran & & $\begin{array}{l}62 \\
57\end{array}$ & $\begin{array}{l}19 \\
22\end{array}$ & $\begin{array}{l}19 \\
21\end{array}$ & $\begin{array}{l}\text { Rats } \\
\text { In vitro } 24 \mathrm{~h}\end{array}$ & $\begin{array}{l}68 \\
66\end{array}$ \\
\hline
\end{tabular}

Both lack of cholesterol lowering (12) and increased plasma cholesterol levels (13) have been observed in pigs caecally infused with propionate. In humans, however, the synthesis of cholesterol from acetic acid decreased when propionate was infused rectally (14), suggesting that the ratio of SCFAs formed upon colonic fermentation may also be of physiological importance.

Butyric acid is the main energy substrate for the colonocytes (15) and is metabolized by the cells in preference to glucose or glutamine, accounting for $70 \%$ of the total energy demand of the colonic mucosa (16). Butyric acid has been reported to be important in the prevention and treatment of diseases of the colonic mucosa, such as distal ulcerative colitis (17) and cancer (18). A diminished oxidation of butyric acid in the colonocytes has been suggested to contribute to the genesis of ulcerative colitis (19). Several clinical studies have been performed, where enemas with an SCFA mixture $(20,21)$ or butyrate alone (22) were associated with reduced symptoms, e.g., bowel frequency, rectal bleeding, and reduced histological scores, in ulcerative colitis patients. The effect appeared to be concentration-dependent, and lower concentrations of butyric acid had no effect (23). A recent intervention study in ulcerative colitis patients has demonstrated reduced symptoms regarding abdominal pain and gastroesophageal reflux when a diet rich in $\beta$-glucans from oats was consumed (Hallert C, Björck I, Nyman M, Grännö C, Svensson H, unpublished results). The $\beta$-glucan rich diet was also associated with an increased faecal concentration of butyric acid; in fact, consumption of $10 \mathrm{~g} \beta$-glucans in the form of oat bran specifically increased the faecal concentration of butyric acid with no effect on the concentration of other SCFAs.

Although butyric acid serves as the primary energy source for the normal colonic epithelium and stimulates growth of colonic mucosa, the growth of colonic tumour cell lines has been reported to be slowed down by butyrate (24). Butyrate also appears to reduce cell differentiation (25) and stimulate apoptosis (26) in tumour cell lines. In rat models, high butyric acid concentration in the colon from fermentation of wheat bran, resistant starch and fructooligosaccharides has been shown to be protective against carcinogenesis in the colon of chemically induced cancer models $(27,28)$. However, Zoran and co-workers found that wheat bran reduced tumour incidence in a rat model independently of butyric acid concentration (29).

In addition to serving as a nutrient to the mucosa cells, SCFAs have other specific colonic effects such as increasing mucosal blood flow (30). Further, the decreased luminal $\mathrm{pH}$ induced by SCFA production may stimulate mineral absorption through increased mineral solubility $(31,32)$. A lower luminal $\mathrm{pH}$ may also reduce secondary bile acid formation (33). Further, SCFAs have been shown to influence the gastrointestinal motility by mechanisms that are not yet fully understood (34).

\section{Impact of substrate}

The content and distribution of SCFAs is dependent on the colonic microflora and/or the type and amount of indigestible carbohydrate available. The bacterial species present in the colon use different fermentation pathways $(35,36)$, leading to differences in the SCFA pattern generated. Indigestible carbohydrates that reach the colon are mainly non-starch polysaccharides (NSP), resistant starches (RS) and certain oligosaccharides. The fermentability of NSP is highly dependent on its physico-chemical properties. Soluble fibres, e.g. pectin and guar gum, are fermented more readily than insoluble fibres, e.g. cellulose and wheat bran. These types of NSP instead, create faecal bulk rather than contribute to SCFA production (37). RS can be classified into three major types (38): starch entrapped in the cell wall of plants and thereby physically inaccessible to $\alpha$ amylase (RS 1); starch stored in granules in the native crystalline form, which can be made accessible to enzymes by gelatinization (RS 2), and finally starch that has retrograded as a result of cooling of gelatinized starch (RS 3). Like NSP, different starches are fermented to various extents $(39,40)$, and in rats retrograded starch has been found to be less fermented than native starch (RS2) (40).

Most mono- and disaccharides are rapidly absorbed in the 
upper intestinal tract and provide a readily available source of energy. An exception is lactose, a $\beta$-linked disaccharide, which is poorly absorbed by most of the adult population in the world due to low levels of lactase in the small intestine (41). When lactose is malabsorbed in the small intestine it reaches the colon for fermentation. Resistant peptides may also enter the colon and amino acid fermentation yields branched SCFAs (i.e. iso-butyric and iso-valeric acid) (42).

It is difficult to study fermentation in man due to the inaccessibility of the proximal colon where the main fermentation takes place. Human studies are thus generally based on indirect measures of fermentation, such as analysis of faecal SCFAs or breath hydrogen. Thus, in vitro and animal models are extensively used to study the formation of SCFAs from indigestible carbohydrates. In vitro studies, where the substrates are incubated with human faecal inocula, are easy to perform, but lack of standardization makes comparisons difficult (43). Further, the food needs to be subjected to in vitro digestion to mimic the action of the small intestine prior to the fermentation tests.

Rats and pigs are the most frequently used animals for fermentation studies. Pigs are colon fermenters, like man, and they also have a similar microflora to man (44). However, in pigs there is also a considerable fermentation in the ileum (45), which may affect the results, and dietary fibre fermentation has been reported to be considerably higher in pigs than in man. In contrast to man, the rat is a caecum fermenter. However, the degree of fermentation of a variety of dietary fibres has been shown to correlate well between rat and man (46). Further, there are similarities in SCFA pattern when comparing in vitro fermentation data for different dietary fibres (i.e. pectin and soybean fibre), using rat and human faecal inocula (47).

The molar distribution of acetic, propionic and butyric acid produced at fermentation of indigestible carbohydrates varies between substrates, as demonstrated in Table 1. Although the relative proportion of the organic end products from fermentation may vary, acetate is the major anion. Pectin is a particularly good source for acetic acid $(48,49)$, whilst arabinogalactan and guar gum are the poorest sources $(48,50,51)$. By contrast, arabinogalactan and guar gum have been shown to give high amounts of propionic acid. Butyric acid production varies over a wide range. Starches have been shown to give high proportions of butyric acid in vitro $(49,50,52)$. In humans it has been demonstrated that administration of an $\alpha$-amylase inhibitor, acarbose, to subjects resulted in enhanced butyric acid in faeces, measured either as concentration or as percentage of total SCFAs (53). However, studies in rats $(54-56)$ and pigs $(45,57,58)$ have shown important variations in fermentation profiles for RS. An explanation could be that the production of butyric acid may vary for different sources of RS. In addition, the time allowed for adaptation of the microflora to the RS may have an impact on the SCFA pattern. We have found in rats fed raw potato starch, that an adaptation period of $4 \mathrm{w}$ gave significantly higher proportions of butyric acid in caecum (19\%) compared to an adaptation period of $2 \mathrm{w}(6 \%)$ (Henningsson $\AA$, Nyman M, Björck I, unpublished results). A prolongation of the adaptation $(6 \mathrm{w}) \mathrm{did}$ not have any further effect on butyric acid proportion. $\beta$-glucans and raffinose are other substrates that have been shown to give high amounts of butyric acid upon fermentation $(48,49,52)$.

In contrast, fermentation of lactose with human faecal inocula in vitro was reported to give mainly acetic acid, and when the amount of lactose increased, the proportion of acetic acid increased further (59). Lactulose is an indigestible disaccharide and is often used to mimic lactose malabsorption. It is completely indigestible (60), and the fermentation pattern is identical to that of lactose (42).

Most studies have been performed on substrates tested as single sources of indigestible carbohydrates, which is not representative of a human diet that contains a complex mixture of carbohydrates. The combination of different indigestible carbohydrates may influence the fermentation pattern, and a mixture of pectin and guar gum gave a higher proportion of butyric acid in the caecum of rats (15\%) compared to the individual substrates (10 and 6\%, respectively) (Henningsson $\AA$, Björck I, Nyman M, unpublished results). Further, the site for SCFA generation in the colon is likely to be dependent on how rapidly fermented the carbohydrate is. Interestingly, it has been demonstrated that the fermentation of easily fermentable high-amylose maize starch could be shifted to the distal colon of rats, when fed in mixture with a slowly fermentable dietary fibre, e.g. psyllium (61). This is an interesting observation since it provides a dietary tool to increase butyric acid formation in the distal colon where most colonic cancers appear in humans (62).

\section{Conclusions and future perspectives}

There are indications that SCFAs may have health-promoting effects, both locally in the colon and systemically, e.g. on glucose and cholesterol metabolism. The design of carbohydrate foods that generate specific SCFApatterns at controlled sites in the large bowel is a challenge for the future with possible health consequences, e.g. in the prevention and treatment of colonic diseases.

\section{REFERENCES}

1. Cummings JH, Macfarlane GT: The control and consequences of bacterial fermentation in the human colon. J Appl Bacteriol 1991;70:443-59.

2. Moore WE, Cato EP, Holdeman LV: Some current concepts in intestinal bacteriology. Am J Clin Nutr 1978;31:S33-42.

3. Ruppin H, Bar-Meir S, Soergel KH, Wood CM, Schmitt MG, Jr.: Absorption of short-chain fatty acids by the colon. Gastroenterology 1980;78 1500-17.

4. McNeil NI: The contribution of the large intestine to energy supplies in man. Am J Clin Nutr 1984;39:338-42.

5. Clausen MR, Mortensen PB: Kinetic studies on the metabolism of shortchain fatty acids and glucose by isolated rat colonocytes. Gastroenterology 1994;106:423-32

6. Remesy C, Demigne C, Morand C: Metabolism and utilization of shor chain fatty acids produced by colonic fermentation. In: Schweizer TF, Edwards CA, eds. Dietary Fibre- A Component of Food, Springer, London, UK 1992; 137-50.

7. Wolever TMS (1995) Short-chain fatty acids and carbohydrate metabolism In J.H. Cummings, J.L. Rombeau, \& T. Sakata, eds. Physiological aspects of short chain fatty acids Cambridge university press, Cambridge.

8. Scheppach W, Pomare EW, Elia M, Cummings JH: The contribution of the large intestine to blood acetate in man. Clin Sci 1991;80:177-82.

9. Thorburn A, Muir J, Proietto J: Carbohydrate fermentation decreases hepatic glucose output in healthy subjects. Metabolism 1993;42:780-5.

10. Anderson JW, Bridges SR: Short-chain fatty acid fermentation products of plant fiber affect glucose metabolism of isolated rat hepatocytes. Proc Soc Exp Biol Med 1984;177:372-6.

11. Chen WJ, Anderson JW, Jennings D: Propionate may mediate the hypocholesterolemic effects of certain soluble plant fibers in cholesterolfed rats. Proc Soc Exp Biol Med 1984; $175: 215-8$

12. Bach Knudsen KE, Canibe N: Changes in pig plasma lipids to dietary cholesterol, source and level of dietary fibre and caecal infusion of propionate. Mechanisms of action of dietary fibre cholesterol on lipid and cholesterol metabolism. In: Lairon D. Ed. COST 92 Metabolic and physiological aspects of dietary fibre in food. Commission of the European communities, Carry le Rouet-Marseille, France, 1993:123-30.

13. Beaulieu KE, McBurney MI: Changes in pig serum lipids, nutrient digestibility and sterol excretion during cecal infusion of propionate. J Nutr $1992 ; 122: 241-5$

14. Wolever TM, Spadafora P, Eshuis H: Interaction between colonic acetate and propionate in humans. Am J Clin Nutr 1991;53:681-7.

15. Roediger WE: Utilization of nutrients by isolated epithelial cells of the rat colon. Gastroenterology 1982;83:424-9.

16. Scheppach W: Effects of short chain fatty acids on gut morphology and function. Gut 1994;35:S35-8

17. Cummings $\mathbf{J H}$ : Short-chain fatty acid enemas in the treatment of distal ulcerative colitis. Eur J Gastoenterol Hepatol 1997;9:149-53.

18. Scheppach W, Bartram HP, Richter F: Role of short-chain fatty acids in the prevention of colorectal cancer. Eur J Cancer 1995;31 A:1077-80.

19. Roediger WE: The colonic epithelium in ulcerative colitis: an energy deficiency disease? Lancet 1980;2:712-5.

20. Breuer RI, Buto SK, Christ ML, Bean J, Vernia P, Paoluzi P, Di Paolo MC Caprilli R: Rectal irrigation with short-chain fatty acids for distal ulcerative colitis. Preliminary report. Dig Dis Sci 1991;36:185-7. 
21. Vernia P, Marcheggiano A, Caprilli R, Frieri G, Corrao G, Valpiani D, Di Paolo MC, Paoluzi P, Torsoli A: Short-chain fatty acid topical treatment in distal ulcerative colitis. Aliment Pharmacol Ther 1995;9:309-13.

22. Scheppach W, Sommer H, Kirchner T, Paganelli GM, Bartram P, Christl S, Richter F, Dusel G, Kasper H: Effect of butyrate enemas on the colonic mucosa in distal ulcerative colitis. Gastroenterology 1992;103:51-6.

23. Steinhart AH, Hiruki T, Brzezinski A, Baker JP: Treatment of left-sided ulcerative colitis with butyrate enemas: a controlled trial. Aliment Pharmacol Ther 1996;10:729-36.

24. Whitehead RH, Young GP, Bhathal PS: Effects of short chain fatty acids on a new human colon carcinoma cell line (LIM1215). Gut 1986;27:1457-63.

25. Barnard JA, Warwick G: Butyrate rapidly induces growth inhibition and differentiation in HT-29 cells. Cell Growth Differ 1993;4:495-501.

26. Hague A, Elder DJ, Hicks DJ, Paraskeva C: Apoptosis in colorectal tumour cells: induction by the short chain fatty acids butyrate, propionate and acetate and by the bile salt deoxycholate. Int J Cancer 1995;60:400-6

27. McIntyre A, Gibson PR, Young GP: Butyrate production from dietary fibre and protection against large bowel cancer in a rat model. Gut 1993;34:386-91.

28. Perrin P, Pierre F, Patry Y, Champ M, Berreur M, Pradal G, Bornet F, Meflah $\mathrm{K}$, Menanteau J: Only fibres promoting a stable butyrate producing colonic ecosystem decrease the rate of aberrant crypt foci in rats. Gut 2001;48:53-61.

29. Zoran DL, Turner ND, Taddeo SS, Chapkin RS, Lupton JR: Wheat bran diet reduces tumor incidence in a rat model of colon cancer independent of effects on distal luminal butyrate concentrations. J Nutr 1997;127:2217-25.

30. Mortensen FV, Nielsen H, Mulvany MJ, Hessov I: Short chain fatty acids dilate isolated human colonic resistance arteries. Gut 1990;31:1391-4.

31. Coudray C, Bellanger J, Castiglia-Delavaud C, Remesy C, Vermorel M, Rayssignuier Y: Effect of soluble or partly soluble dietary fibres supplementation on absorption and balance of calcium, magnesium, iron and zinc in healthy young men. Eur J Clin Nutr 1997;51:375-80.

32. Younes H, Demigne C, Remesy C: Acidic fermentation in the caecum increases absorption of calcium and magnesium in the large intestine of the rat. Br J Nutr 1996;75:301-14.

33. Macdonald IA, Singh G, Mahony DE, Meier CE: Effect of $\mathrm{pH}$ on bile salt degradation by mixed fecal cultures. Steroids 1978;32:245-56.

34. Cherbut C, Aube AC, Blottiere HM, Galmiche JP: Effects of short-chain fatty acids on gastrointestinal motility. Scand J Gastroenterol Suppl 1997;222:58-61.

35. Moore WE, Holdeman LV: Human fecal flora: the normal flora of 20 Japanese-Hawaiians. Appl Microbiol 1974;27:961-79.

36. Holdeman LV, Cato EP, Moore WEC: Anaerobic Laboratory Manual. Virginia Polytechnic Institute and State University, Blackburg, Virginia, USA 1977.

37. Nyman M, Asp NG: Fermentation of dietary fibre components in the rat intestinal tract. Br J Nutr 1982;47:357-66.

38. Englyst HN, Kingman SM, Cummings JH: Classification and measurement of nutritionally important starch fractions. Eur J Clin Nutr 1992;46 Suppl 2:S33-50.

39. McBurney MI, Cuff DJ, Thompson LU: Rates of fermentation and short chain fatty acid and gas production of six starches by human faecal microbiota. J Sci Food Agric 1990;50:79-88.

40. Schulz AG, Van Amelsvoort JM, Beynen AC: Dietary native resistant starch but not retrograded resistant starch raises magnesium and calcium absorption in rats. J Nutr 1993;123:1724-31.

41. Büller HA, Grand RJ: Lactose intolerance. Annu Rev Med 1990;41:141-8.

42. Mortensen PB, Holtug K, Rasmussen HS: Short-chain fatty acid production from mono- and disaccharides in a fecal incubation system: implications for colonic fermentation of dietary fiber in humans. J Nutr 1988;118:321-5.

43. Cummings JH, Edwards C, Gee JM, Nagengast FM, Mathers JC: Physiological effects of resistant starch in the large bowel. In: Asp N-G, van Amelsvoort JMM, Hautvast JGAJ, eds. Concluding plenary meeting of EURESTA: including the final reports of the working groups. EURESTA, Wageningen 1994;38-55.

44. Mitsuoka T, Kaneuchi C: Ecology of the bifidobacteria. Am J Clin Nutr 1977;30:1799-1810.

45. Martin LJM, Dumon HJW, Champ MMJ: Production of short-chain fatty acids from resistant starch in a pig model. J Sci Food Agric 1998;77:71-80.

46. Nyman M, Asp NG, Cummings J, Wiggins H: Fermentation of dietary fibre in the intestinal tract: comparison between man and rat. $\mathrm{Br} \mathrm{J}$ Nutr 1986;55:487-96.

47. Barry JL, Hoebler C, Macfarlane GT, Macfarlane S, Mathers JC, Reed KA Mortensen PB, Nordgaard I, Rowland IR, Rumney CJ: Estimation of the fermentability of dietary fibre in vitro: a European interlaboratory study. $\mathrm{Br}$ J Nutr 1995;74:303-22.

48. Berggren AM, Björck IM, Nyman EM, Eggum BO: Short-chain fatty acid content and $\mathrm{pH}$ in caecum of rats given various sources of carbohydrates. J Sci Food Agric 1993;63:397-406.

49. Casterline JLJ, Oles CJ, Ku Y: In vitro Fermentation of Various Food Fiber Fractions. J Agric Food Chem 1997;45:2463-7.

50. Englyst HN, Hay S, Macfarlane GT: Polysaccharide breakdown by mixed population populations of human faecal bacteria. FEMS Microbiol Ecol 1987;45:163-71.

51. McBurney MI, Thompson LU: Effect of human faecal inoculum on in vitro fermentation variables. Br J Nutr 1987;58:233-43.

52. Bradburn DM, Mathers JC, Gunn A, Burn J, Chapman PD, Johnston ID: Colonic fermentation of complex carbohydrates in patients with familial adenomatous polyposis. Gut 1993;34:630-6.

53. Weaver GA, Tangel CT, Krause JA, Parfitt MM, Jenkins PL, Rader JM, Lewis BA, Miller TL, Wolin MJ: Acarbose enhances human colonic butyrate production. J Nutr 1997;127:717-23.

54. Le Blay G, Michel C, Blottiere HM, Cherbut C: Enhancement of butyrate production in the rat caecocolonic tract by long-term ingestion of resistant potato starch. Br J Nutr 1999;82:419-26.

55. De Schrijver R, Vanhof K, Vande Ginste J: Effect of enzyme resistant starch on large bowel fermentation in rats and pigs. Nutr Res 1999;19:927-6.

56. Berggren AM, Björck IM, Nyman EM, Eggum BO: Short-chain fatty acid content and $\mathrm{pH}$ in caecum of rats fed various sources of starch. J Sci Food Agric 1995;68:241-8

57. Bird AR, Hayakawa T, Marsono Y, Gooden JM, Record IR, Correll RL, Topping DL: Coarse brown rice increases fecal and large bowel short-chain fatty acids and starch but lowers calcium in the large bowel of pigs. J Nutr 2000;130:1780-17.

58. Brown I, Warhurst M, Arcot J, Playne M, Illman RJ, Topping DL: Fecal numbers of bifidobacteria are higher in pigs fed Bifidobacterium longum with a high amylose cornstarch than with a low amylose cornstarch. J Nutr 1997;127:1822-7.

59. Holtug K, Clausen MR, Hove H, Christiansen J, Mortensen PB: The colon in carbohydrate malabsorption: short-chain fatty acids, $\mathrm{pH}$, and osmotic diarrhoea. Scand J Gastroenterol 1992;27:545-52.

60. Saunders DR, Wiggins HS: Conservation of mannitol, lactulose, and raffinose by the human colon. Am J Physiol 1981;241:G397-402.

61. Morita T, Kasaoka S, Hase K, Kiriyama S: Psyllium shifts the fermentation site of high-amylose cornstarch toward the distal colon and increases fecal butyrate concentration in rats. J Nutr 1999;129:2081-7.

62. Bufill JA: Colorectal cancer: evidence for distinct genetic categories based on proximal or distal tumor location. Ann Intern Med 1990;113:779-88.

63. Brighenti F, Testolin G, Canzi E, Ferrari A, Wolever TMS, Ciappellano S, Porrini M, Simonetti P: Influence of long-term feeding of different purified dietary fibers on the volatile fatty acid (VFA) profile, $\mathrm{pH}$ and fiberdegrading activity of the cecal contents in rats. Nutr Res 1989;9:761-72.

64. Vince AJ, McNeil NI, Wager JD, Wrong OM: The effect of lactulose, pectin arabinogalactan and cellulose on the production of organic acids and metabolism of ammonia by intestinal bacteria in a faecal incubation system. Br J Nutr 1990;63:17-26.

65. Roland N, Nugon-Baudon L, Andrieux C, Szylit O: Comparative study of the fermentative characteristics of inulin and different types of fibre in rats inoculated with a human whole faecal flora. Br J Nutr 1995;74:239-49.

66. Karppinen S, Liukkonen K, Aura A-M, Forssell P, Poutanen K: In vitro fermentation of polysaccharides of rye, wheat and oat brans and inulin by human faecal bacteria. J Sci Food Agric 2000;80:1469-76.

67. Hara H, Haga S, Kasai T, Kiriyama S: Fermentation products of sugar-beet fiber by cecal bacteria lower plasma cholesterol concentration in rats. J Nutr 1998;128:688-93

68. Lu ZX, Gibson PR, Muir JG, Fielding M, O'Dea K: Arabinoxylan fiber from a by-product of wheat flour processing behaves physiologically like a soluble fermentable fiber in the large bowel of rats. J Nutr 2000;130:1984-90. 